\title{
Pelatihan Penelitian Tindakan Kelas Tingkat Lanjut Bagi Guru Sekolah Dasar Kecamatan Sukoharjo
}

\author{
Sutoyo $^{1}$ dan Wartoyo ${ }^{2}$ \\ ${ }^{1,2}$ Program Studi Pendidikan Pancasila dan Kewarganegaraan \\ Fakultas keguruan dan IImu Pendidikan
}

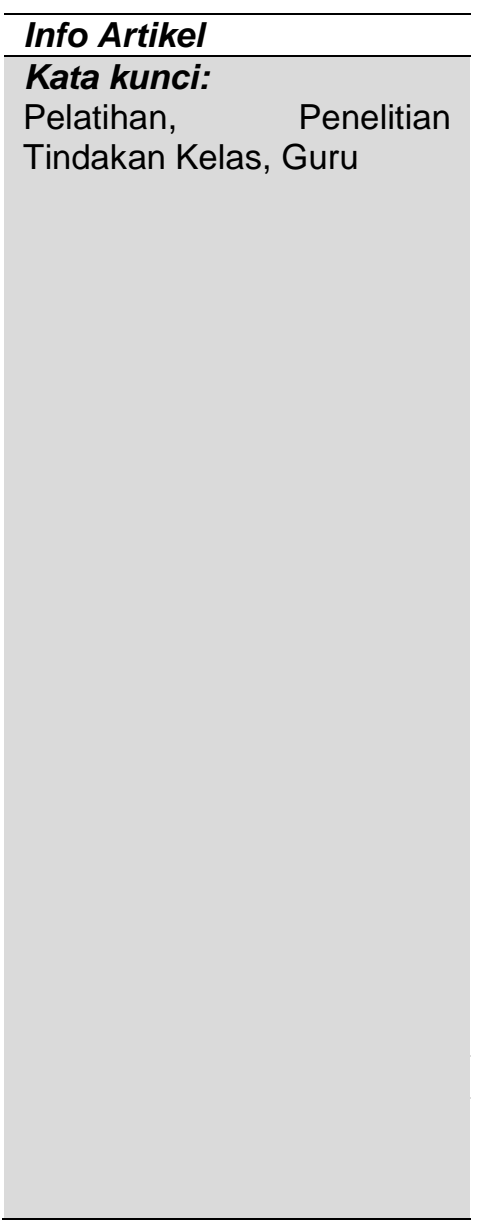

\begin{abstract}
Abstrak
Sebagai seorang guru perlu memahami penelitian tindakan kelas. Penelitian tindakan kelas merupakan upaya untuk mengatasi masalah pembelajaran yang dilakukan oleh guru secara individu maupun kelompok yang dilaksanakan di kelas maupun di luar kelas. Kegiatan pengabdian kepada masyarakat ini bertujuan untuk : 1). Membantu para guru dalam menyelesaikan permasalahan pembelajaran; 2). Melatih para guru Sekolah dasar agar memiliki kemampuan dalam melakukan penelitian tindakan kelas. Target yang akan dicapai pada pengabdian masyarakat ini adalah $75 \%$ dari sejumlah guru Sekolah Dasar di kecamatan Sukoharjo peserta diklat dapat melakukan penelitian tindakan kelas. Pengabdian kepada masyarakat ini sasarannya adalah para guru Sekolah Dasar di kecamatan Sukoharjo yang telah mengikuti diklat pada tingkat dasar sejumlah 50. Adapun yang menjadi mitra dalam kegiatan ini adalah Dinas pendidikan kecamatan Sukoharjo. Teknik yang digunakan dalam pelatihan ini meliputi diskusi, penugasan, pendampingan dan pembimbingan. Hasil pengabdian masyarakat ini, menunjukkan bahwa : 1). Secara proses para guru mengikuti pelatihan secara baik, taat azas dan mempunyai motivasi yang tinggi; 2). Dari 50 guru yang mengikuti pelatihan penelitian tindakan kelas 35 guru dapat melakukan penelitian dengan benar. Sedangkan 15 guru sudah mampu menyususn proposal penelitian tetapi belum dapat melakukan penelitian dengan benar.
\end{abstract}

\section{PENDAHULUAN}

Berdasarkan UU No. 14 Tahun 2005 tentang guru dan dosen, disebutkan, bahwa guru wajib memiliki kualifikasi akademik, kompetensi, sertifikat pendidik, sehat jasmani dan rohani serta memiliki kemampuan untuk mewujudkan tujuan pendidikan nasional.. Adapun kompetensi yang harus dimiliki oleh para guru meliputi, kompetensi profesional, kompetensi paedagogik, kompetensi sosial dan kompetensi personal. Kompetensi yang dimiliki oleh para guru harus dapat diimplementasikan dalam proses pembelajaran.

Dalam menjalankan tugas keprofesionalan guru berkewajiban merencanakan pembelajaran, melaksanakan proses pembelajaran yang bermutu serta menilai dan mengevaluasi hasil pembelajaran. Apabila dalam melaksanakan proses pembelajaran ada kekurang berhasilan dalam pencapaian tujuan, maka guru harus mencari solusi dengan berbagai cara. Salah satu cara untuk mengatasi kegagalan dalam proses pembelajaran guru disarankan untuk melakukan penelitian tindakan kelas.

Penelitian tindakan kelas merupakan penelitian yang dilakukan guru secara individu ataupun kelompok untuk mengatasi permasalahan pembelajaran baik di kelas maupun di luar kelas. Mengingat pentingnya penelitian tindakan kelas sebagai upaya untuk mengatasi masalah pembelajaran, pemerintah mewajibkan para guru untuk melakukan penelitian tindakan kelas sebagai syarat untuk kenaikan pangkat. 
Secara realita para guru mengalami kesulitan dalam melakukan penelitian tindakan kelas. Dampaknya banyak persoalan pembelajaran tidak teratasi. Disamping itu para guru banyak yang kenaikan pangkatnya tertunda.Pada diklat tingkat dasar atau tahap pertama telah dilakukan sampai pada tahap pembuatan proposal. Oleh karena itu perlu dilanjutkan pada tahap pelaksanaan penelitian dan pembuatan laporan.

Permasalahan utama yang dihadapi mitra adalah 1). Rendahnya kemampuan guru dalam mengatasi permasalahan pembelajaran: 2). Minimnya kemampuan dalam malakukan penelitian tindakan kelas; 3). Kenaikan pangkat para guru tertunda.

Persoalan yang dihadapi seperti diuraikan di atas dapat di atasi melalui pelatihan penelitian tindakan kelas tingkat lanjut. Melalui pelatihan diyakini akan dapat mengatasi persoalan yang dihadapi oleh para guru sekolah dasar yang ada di kecamatan Sukoharjo.

\section{METODE PELAKSANAAN}

\section{A. Sasaran Pengabdian Masyarakat}

Sasaran pengabdian masyarakat ini adalah para guru sekolah dasar di kecamatan Sukoharjo, kabupaten Sukoharjo yang telah mengikuti diklat tingkat dasar sejumlah 50 guru.

B. Mitra Pengabdian Pengabdian Masyarakat

Mitra pengabdian masyarakat ini adalah Dinas Pendidikan Kecamatan Sukoharjo, kabupaten Sukoharjo.

\section{Metode yang digunakan}

Diklat ini menggunakan metode diskusi, penugasan, pendampingan dan pembimbingan.

D. Prosedur atau langkah - langkah Kerja

1. Wawancara dan observasi awal.

2. Pengurusan ijin pengabdian masyarakat.

3. Membuat kesepakan tentang tempat, hari dan tanggal pelaksanaan.

4. Penyusunan instrumen pengabdian masyarakat.

5. Pembentukan kelompok peserta pelatihan.

6. Pelaksanaan pelatihan.

7. Evaluasi

8. Pelaporan

\section{E. Partisipasi Mitra}

Wujud partisipasi mitra yakni :

1. Mengundang para guru peserta pelatihan.

2. Memberi sambutan dan penngarahan pada saat pembukaan acara pelatihan.

3. Memantau pelaksanaan pelatihan.

4. Memberikan evaluasi dan masukan pelaksanaan pelatihan.

5. Memberikan sertifikat pelatihan.

\section{HASIL DAN PEMBAHASAN}

\section{A. Hasil Proses (kualitatif).}

Dalam pelaksanaan pelatihan para guru mengikuti ketentuan yang telah disepakati dalam pelatihan. Dimana seluruh peserta pelatihan harus mengikuti pelatihan secara penuh.. Realitasnya para guru mentaati dan mengikuti seluruh proses pelatihan. Hal ini disebabkan para guru menyadari pentingnya penelitian tindakan kelas. Di samping itu para guru merasa belum secara utuh memahami bagaimana melaksanakan penelitian tindakan kelas dan menyusun laporan penelitian.

Dalam proses pelatihan pserta harus menyusun proposal, melaksanakan penelitian dan melaporkan hasil penelitian untuk mendapatkan bimbingan. Proses mengerjakan tugas-tugas dari instrukur secara terstrukur dan mandiri dilaksanakan oleh para guru dengan baik. Dalam hal ini para guru mempunyai motivasi untuk dapat melaksanakan dan menyusun laporan penelitian tindakan kelas.

Draf laporan penelitian dikumpulkan dan dilakukan pembimbingan secara kelompok. Proses bimbingan yang dilakukan diikuti secara seksama oleh para peserta pelatihan. Keberhasilan secara 
proses ini tidak terlepas dari peran koordinator guru dan ketua kelompok dalam pelatihan. Hal ini disebabkan koordinator dan ketua kelompok selalu memberikan motivasi kepada para guru untuk terus mengikuti kegiatan pelatihan secara sungguh-sungguh. Karena kesungguhan merupakan kunci kebethasilan.

B. Hasil kuantitatif.

Pada umunya para guru sudah mampu melaksanakan penelitian tindakan kelas dan mampu menyusun laporan penelitian tindakan kelas. Secara kuantitatif dari peserta yang berjumlah 50 guru, 35 berhasil dengan baik. Dimana para guru mampu melaksanakan penelitian dan menyusun laporan penelitian tindakan kelas dengan benar. Keberhasilan ini disebabkan tingkat motivasi para guru ini tinggi. Motivasi merupakan dorongan dari diri seseorang dalam mengikuti suatu aktivitas.

Para guru yang kurang berhasil berjumlah 15 orang. Dimana 15 guru ini sudah melaksanakan penelitian, namun dalam menyusun laporan masih banyak kesalahan. Hal ini disebabkan pemahaman para guru dalam penyususnan laporan penelitian kurang utuh, disamping itu juga disebabkan para guru kurang teliti dalam penyususnan laporan.

\section{KESIMPULAN DAN SARAN}

A. Kesimpulan

1. Para guru mempunyai motivasi yang tinggi dalam mengikuti pelatihan penelitian tindakan kelas dari awal sampai akhir.

2. Para guru pada umunya sudah mampu melaksanakan penelitian tindakan kelas dan mampu menyususn laporan penelitian tindakan kelas dengan benar.

B. Saran-saran

1. Hendaknya para terus berlatih melakukan penelitian tindakan kelas sebagai upaya mengatasi masalah pembelajaran.

Hendaknya dinas pendidikan kecamatan selalu melakukan upaya peningkatan pemahaman guru tentang penelitian tindakan kelas secara berkelanjutan.

\section{REFERENCES}

Nana Syaodih Sukmadinata. (2013). Metode Penelitian Pendidikan. Bandung : Remaja Rosdakarya. Punaji Setyowati. (2012). Metode Penelitian pendidikan. Jakarta : Kencana Prenada Media Grup

Rameli Agam. (2009). Menulis Karya IImiah. Yogjakarta : Famelia Pustaka

Sugiyono. (2013). Metode Penelitian Pendidikan. Bandung : Alfabrta

Suyadi. (2010). Panduan Penelitian Tindakan Kelas. Yogjakarta. Diva Prees. 